\title{
Indigenous Theory is Theory: Whakapapa for Archaeologists
}

\author{
Yvonne Marshall
}

\begin{abstract}
Drawn by their foundation in fundamentally 'otherwise' posthuman ethical and moral worlds, archaeologists have in recent years employed a number of indigenous theories to interpret archaeological materials. In this paper I consider the potential of New Zealand Maori whakapapa, loosely and reductively translatable as genealogy or ancestry, to become a strand of general theory in archaeology. The qualities of whakapapa which I feel have particular potential are its moral and ethical embeddedness and its insistence on multiple forms of relating. Importantly, whakapapa has an accessible indigenous voice. There is an extensive published literature, both Maori and non-Maori, academic and general, discussing, interpreting and applying Maori social theory, including whakapapa. In addition, whakapapa remains today fundamental to everyday and ceremonial Maori life. It is lived. Employing whakapapa as archaeological theory does not, then, depend on a having a specific authoritative interpreter. Here I have taken recent work by installation artist Maureen Lander as a forum to outline the key principles of whakapapa and to inform my discussion of whakapapa as archaeological theory.
\end{abstract}

\section{Introduction}

As Park et al. (2011, 8; Hountondji 2002) argue, it is high time we stopped reducing 'what might be construed as indigenous social theory to data, rather than recognising it as theory'. It is time to 'put indigenous knowledges to work' rather than just treating them with 'exquisite politeness' (Gillett 2009, 11; Park et al. 2011, 8). Indigenous voices speak to similar frustrations. The Te Hau Mihi Ata research project in New Zealand, for example, was set up 'to negotiate spaces for and develop processes of dialogue that allow for a deeper level of interaction between matauranga Maori (Maori indigenous knowledge) and science'. 'The genesis of the project was motivated by community concerns at the framing of matauranga Maori (indigenous knowledge) as only relevant in a traditional context'. In response, the project sought to 'unlock' the innovation potential of Maori knowledge, people and resources'
(Hudson et al. 2012, 11-12) by considering how it might inform new biotechnologies in unanticipated ways.

My aim in this paper is more modest. First I introduce the Maori theory of whakapapa; what it is, how it is understood; how it is employed by Maori and by non-Maori academics in New Zealand. My hope is this brief overview of current thinking around ideas of whakapapa as social and scientific theory may inspire a wider community to examine these ideas more closely and consider employing them in innovative ways. To conclude, I point briefly to how whakapapa might be 'unlocked' or 'put to work', as archaeological theory.

Whakapapa is loosely, and reductively, translatable as genealogy or ancestry, but includes connotations of layering, and to lay flat (Lander 2017; Ngata 2019; J. Roberts 2006; Salmond 2019). Like other indigenous theories recently favoured by archaeologists, whakapapa is 'inherently values based' (Hudson et al.

Cambridge Archaeological Journal 31:3, 515-524 @ The Author(s), 2021. Published by Cambridge University Press on behalf of the McDonald Institute for Archaeological Research. This is an Open Access article, distributed under the terms of the Creative Commons Attribution licence (http:// creativecommons.org/licenses/by/4.0/), which permits unrestricted re-use, distribution, and reproduction in any medium, provided the original work is 
$2012,12)$. It constitutes a moral and ethical framework for living founded in what western theory would describe as a posthuman world-namely, a world which does not acknowledge any fundamental division between humans, other living forms and the material, spiritual and social environments in which all live (M. Roberts 2012; M. Roberts et al. $2004,4)$. Whakapapa is both theory and practice; it is a way of thinking, being and acting. M. Roberts $(2010,1)$ describes it as a 'mind-map', 'a genealogical framework upon which spiritual, spatial, temporal and biophysical information about a particular place is located'.

While whakapapa has much in common with western ideas of genealogy and evolutionary theory, there are fundamental differences (Gillett 2009; Salmond 2019). As Hudson et al. $(2012,13)$ argue with respect to scientific knowledge, critical 'differences lie in the way knowledge is assembled and in the ways in which people, practices and places become connected and form knowledge spaces'. These differences are powerful, and the difficulties which arise when seeking to develop 'a creative interface between different knowledge systems' should not be underestimated. However, with time, positive engagement, acknowledgement and respect, a 'negotiated space' can be opened (Hudson et al. 2012, 14).

\section{Indigenous voice}

Archaeologists are increasingly employing indigenous theories to interpret archaeological materials. Among the attractions of indigenous theories is their foundation in fundamentally 'otherwise' posthuman ethical and moral worlds (cf. Alberti et al. 2011). Unsurprisingly a common subject for interpretation is forms of 'artwork'. Whether ancient, modern or contemporary, art is a forum through which people seek to explore and express something of the profundities of life and living-art takes the shape of a material enquiry into the world. Shamanism, for example, has been highly influential in the interpretation of southern African rock art (Dowson 1998; Tomášková 2013). More recently, perspectivism (Viveiros de Castro 1998; 2004) and animism (Willerslev 2007) have attracted considerable interest.

Unfortunately, academic use of these indigenous theories is fundamentally dependent on an anthropological interpreter, commonly a single authoritative voice, to make them accessible to other academics, including archaeologists. Indigenous voices come to us in academic anthropological writing, rather than speaking directly for themselves. Many archaeologists find this situation unsatisfactory and indigenous voices are increasingly heard directly in published archaeological writing (e.g. Nicholas 2010). In addition, archaeologists have actively sought insight in published indigenous writing, such as the work of Vine Deloria (2003).

Whakapapa is a social theory with a strong, accessible indigenous voice. A special issue of The Journal of the Polynesian Society, focused on whakapapa, has highlighted the influential work of Maori scholars during the early twentieth-century development of anthropology in New Zealand (Lythberg \& McCarthy 2019). As part of this work, the national Board of Maori Ethnological Research, Te Poari Whakapapa, established by Apirana Ngata, identified anthropology as a key vehicle for promoting Maori self-identified development (McCarthy \& Tapsell 2019; Ngata 2019). Numerous Maori-authored publications have subsequently described and interpreted whakapapa for both Maori and non-Maori audiences (Hudson et al. 2007; Mahuika 2019; J. Roberts 2006; M. Roberts 2010; 2012; 2013). For those who wish to find it, Maori scholarship on whakapapa is accessible in published forums and need not be read through an anthropological interpreter.

Beyond academic writing, whakapapa remains fundamental to both everyday and ceremonial Maori life. Some contexts for the practice of whakapapa are socially restricted, such as formal or ceremonial events on marae where speeches based in whakapapa are delivered by authoritative cultural experts. But whakapapa also resides in museums, in cultural centres, and is lived everywhere, every day, even in the use of humble objects (Maihi \& Lander 2008). It can be encountered and experienced by any visitor to New Zealand who chooses to take an interest.

\section{What is whakapapa?}

Western genealogies are presented as a formal ordering of persons arranged as a branching tree. There is presumed to be a 'correct' structure (cf. Ingold 2007; 2011). In contrast, whakapapa are dynamic and relational, 'a cosmological system for reckoning degree of similarity and difference, determining appropriate behaviour, and manipulating existing and potential relationships to achieve desired effects' (Henare 2007, 57). Whakapapa are not essentialist schemas that determine who a person is, or who is/is not a member of a specific group. Whakapapa do not fix identities; they frame possibilities. They set out differences and commonalities in a contingent, positioned frame rather than in categorical terms. A 

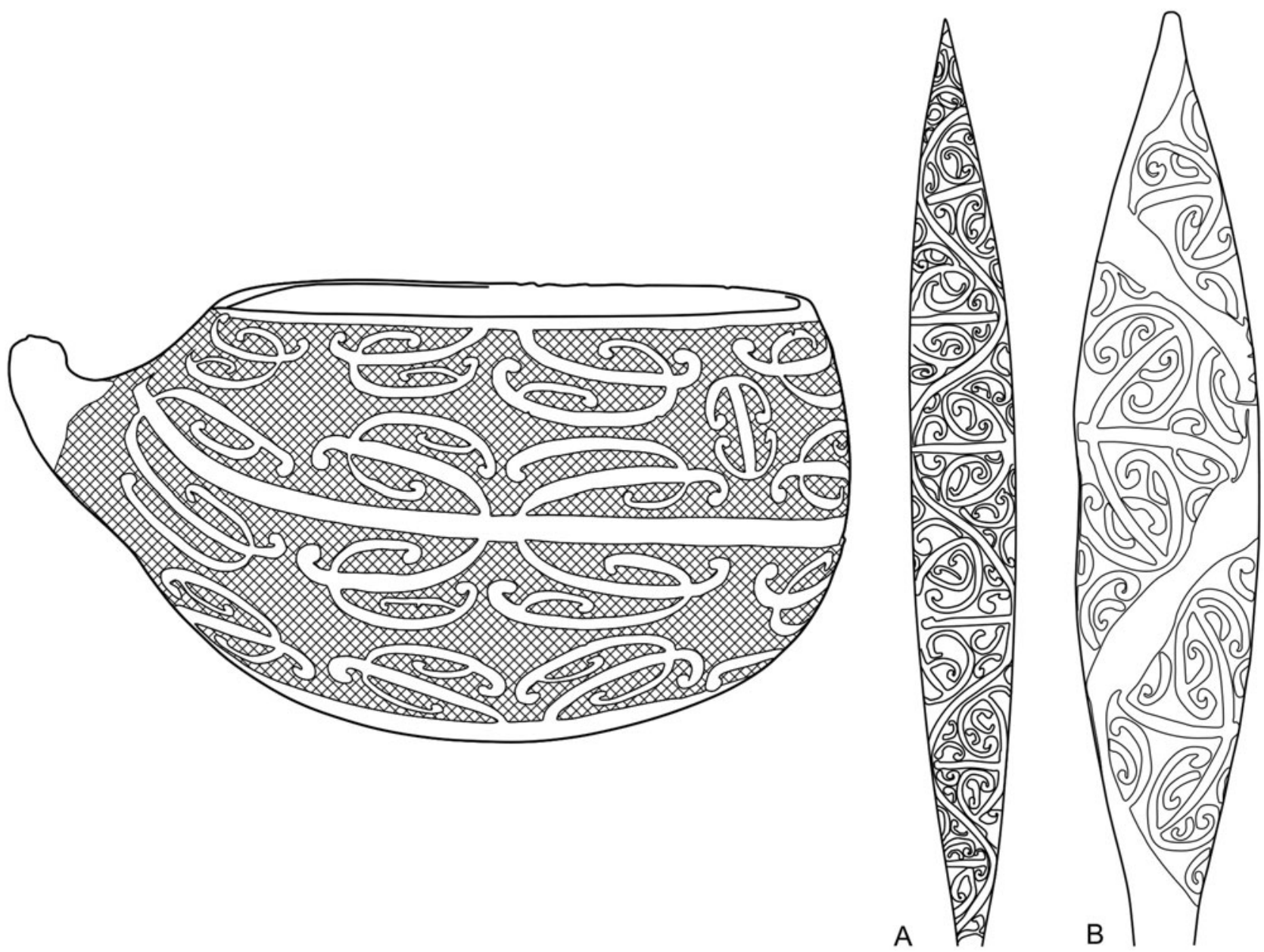

Figure 1. Kowhaiwhai designs based on the growing habit of the gourd plant or hue (left). Early nineteenth-century incised gourd container. The background fill of the design has been simplified to highlight the formline or manawa lines. Length $32 \mathrm{~cm}$. (Collection of the British Museum. Starzecka et al. 2010, 42, no. 187.) (A) Early nineteenth-century painted canoe paddle or hoe. Complete length including handle (not shown) $202.5 \mathrm{~cm}$. (Auckland Museum, 22068.3. Neich 1993, 68.) (B) Late eighteenth-century painted canoe paddle or hoe. Complete length including handle (not shown) $180 \mathrm{~cm}$. (Cambridge University Museum, Cook collection; Neich 1993, 64.) (Drawings: Penny Copeland.)

whakapapa always speaks to the requirements and desired outcomes of the particular persons, context and situation in which it is presented-it is always contextual, situated and purposeful.

A key metaphor for whakapapa is the gourd plant or hue, Cucurbita lagenaria vulgaris (Neich 1993, 39), never a tree (Ngata 2019, 26). In contrast to the metaphor of a fixed, rigidly upright, branching tree, a gourd plant takes its shape and direction from the context or environment in which it grows. It is a vine which scrambles along the ground, up and over whatever it encounters. Whakapapa is situated knowledge (cf. Haraway 1991). A whakapapa speaks from a specific geographically, socially, even mythically embodied place. In addition, it speaks purposefully. Although its direction is open and contingent, it is always responding to a stated problem, question or purpose. A whakapapa can never become generalized truth; it is always specific and explicitly purposeful and therefore also ethically and morally engaged.

Whakapapa is materialized in many, if not all, Maori art forms. Most spectacular of these is the decoration on and in a whare whakairo, a large decorated meeting-house which forms part of the marae complex where events are held to mark life-crisis celebrations and hold important meetings. Formal speeches based in whakapapa take place both inside and on the open ground directly in front of the house. The wood carvings, woven tukutuku boards and painted kowhaiwhai rafter designs which adorn the house all speak in whakapapa, each in their own way. Kowhaiwhai designs, for example, take the form of trailing 
a
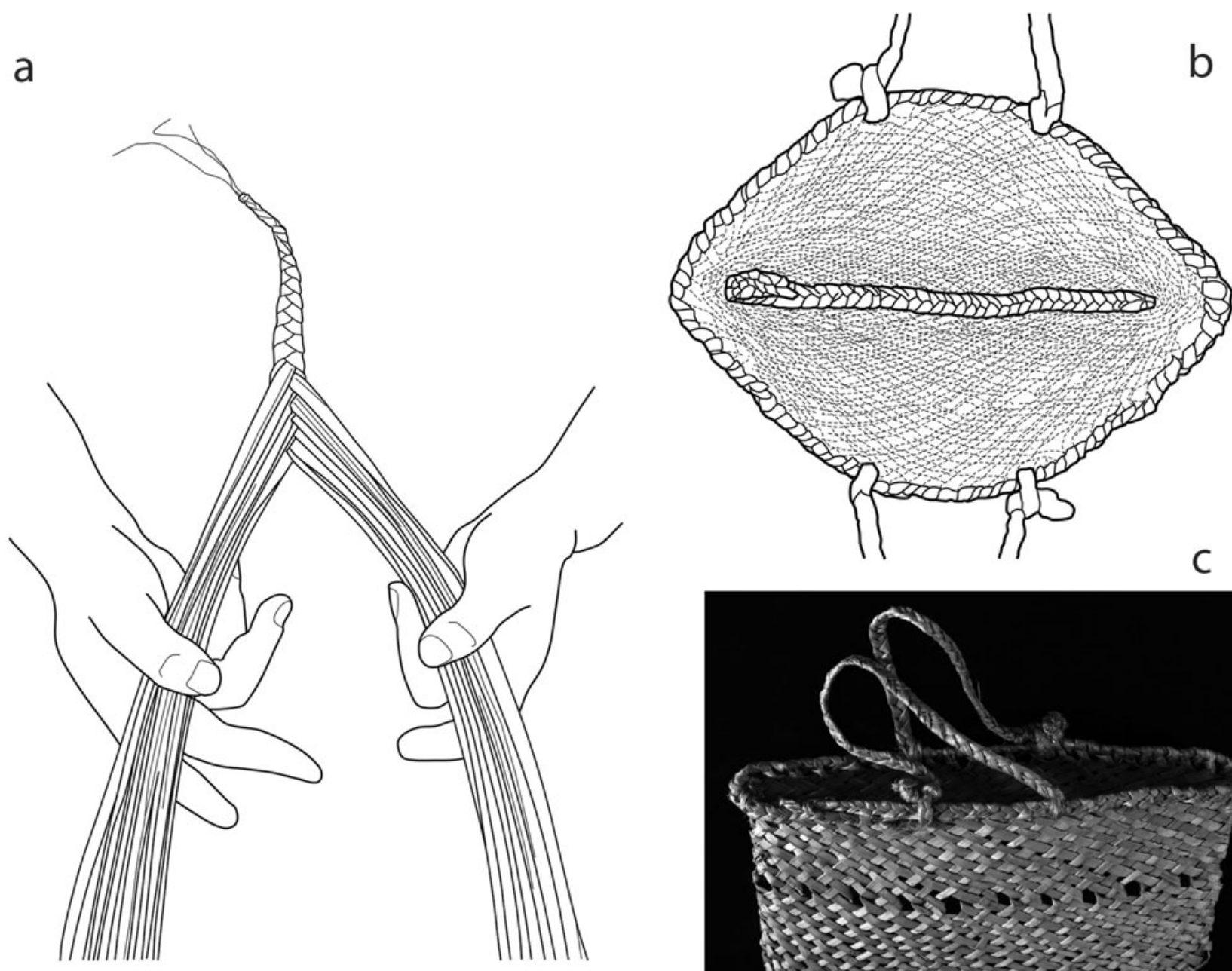

$\mathrm{b}$

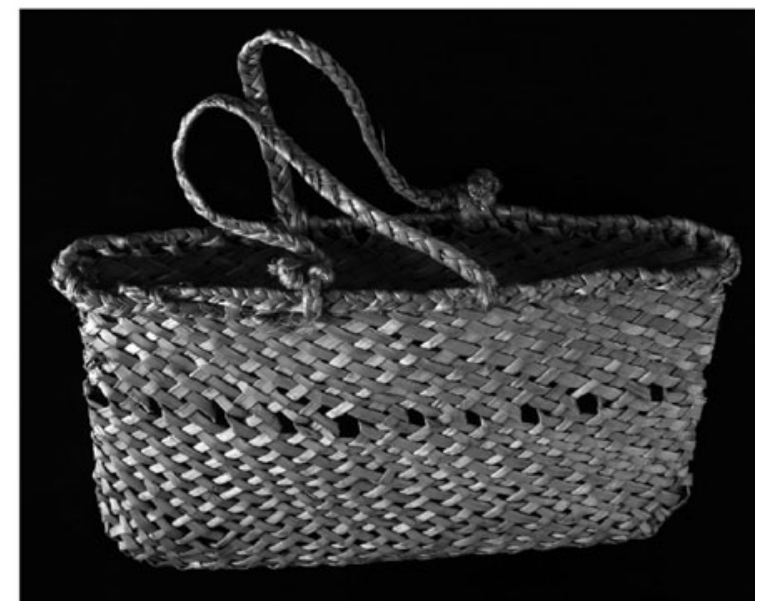

Figure 2. Weaving a flax kete. (a) Beginning a foundational braid or whiri from which the weaving of a kete will be grown. (Drawn from a 1921 Alexander Turnbull Library photograph PA1-q-257-42-5. Paama-Pengelly 2010, 43.)

(b) The completed foundation braid runs along the inside, forming the base of a finished kete. (Drawing: Penny Copeland.)

(c) In a completed kete the braid is hidden from outside view. (Photograph: Andrew Crosby, author's collection.)

gourd plants (Neich 1993; 2001), and were once common on canoe paddles and gourd containers (Fig. 1).

But whakapapa is also everyday practice. Take, for example, the woven flax basket, the kete, possibly the most ubiquitous and versatile item of all Maori material culture. Most people in New Zealand have one and most Maori have several. They are used for anything and everything; as planters, to carry laundry, a purse for formal social occasions and more metaphorically as 'baskets of knowledge' (Maihi \& Lander 2008). They may even be employed to carry dreams (Maihi \& Lander 2008, 70). Thus the social lives of kete are entwined with those who use them; 'every kete has a story' (Maihi \& Lander 2008).
Construction of a kete follows a parallel path to the narration of a whakapapa. It begins with a foundation plait, as shown in Figure 2a, drawn from a 1921 photograph by James McDonald (Salmond \& Lythberg 2019). The initial threads are fine and thin but build substance as additional strips of prepared flax, harakeke (Phormium tenax), are progressively worked in. The long, unplaited flax ends are then used to weave the body of the kete, in the process encasing the foundation braid inside the kete to form its base (Fig. 2b). When finished, the foundation braid lies hidden inside (Fig. 2c), unless the kete is opened out for use.

In her most recent installation, Flat Pack Whakapapa, multi-media artist Maureen Lander 


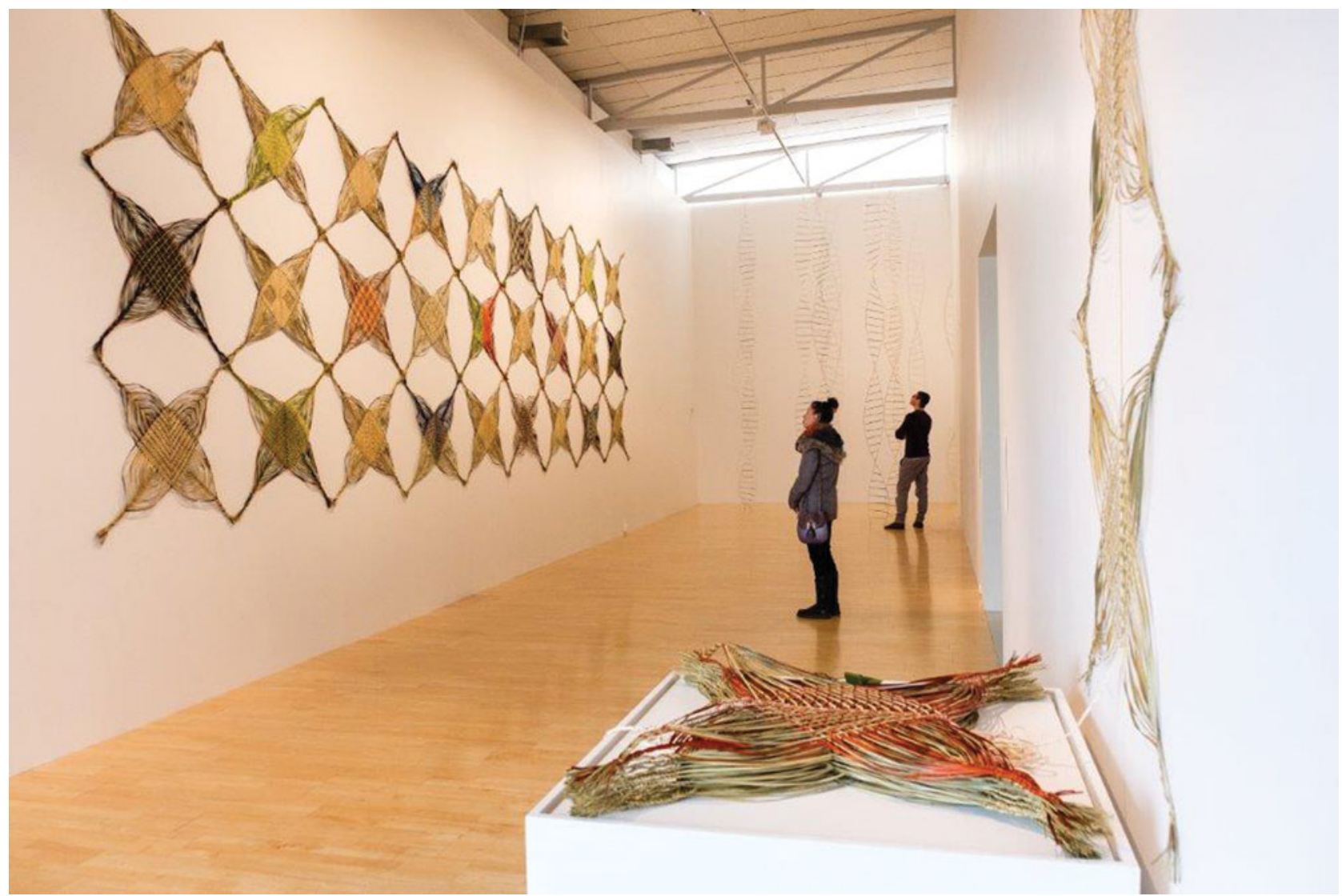

Figure 3. Three components of Maureen Lander's installation Flat-Pack Whakapapa, as displayed in the Dowse Art Museum Exhibition Space, 2018. On the rear wall: diy-DNA, 2017, haraheke, muka. (Collection of the Dowse Art Museum, purchased 2017.) In the right foreground: Flat-Pack Whakapapa, 2017, harakeke, muka. (Collection of the artist.) Along the left side wall: Kit-Set Whanaungatanga, 2017, harakeke, Teri dyes. (Collection of the artist and her weaving collaborators.) (Photograph: Mark Tantrum.)

explores this connection between kete, whakapapa and weaving, linking it also to genetics (Lander 2017). Her work was displayed in the exhibition space at the Dowse Art Museum in 2017 and is currently touring other venues across New Zealand (Mata Aho Collective 2017; Dowse 2017; Lander 2017). The installation is composed of three parts; diy-DNA, Flat-Pack Whakapapa and Kit-Set Whanaungatanga (Fig. 3). Each part plays provocatively with the idea that because whakapapa is 'always with us' it can be 'packed down', 'carried around, reconfigured and added onto later'; 'whakapapa grows with us' (Dowse 2017).

In Figure 3, diy-DNA is positioned along the rear wall. It consists of huge DNA strands made from rolled flax leaves with braided muka [flax fibre] which visitors can walk amongst. It is a gentle provocation to question and challenge new biotechnologies such as Ancestry DNA websites and gene manipulation processes. It is also explorative; 'diy-DNA opens a space to consider why similar narratives unfold within different cultures and religions, and how mythology, science and technology have all been used to try to understand where we come from, and what makes us who we are' (Dowse 2017).

On the wall to the right is Flat-Pack Whakapapa. It draws on two core meanings of whakapapa: to line up, as in genealogy, and to lie flat or place in layers. A continuous line of opened (flat-packed) kete extends vertically up the wall and down into a horizontal pile. Each kete is joined to its neighbours by the ends of its four finishing braids (see Figure 4). The four vertical kete are ancestors, who came before us but 'guide us into the future'; the top horizontal kete is the present, and our descendants follow into the pile beneath. Every kete, every person, is both unique in themselves and composed by connections to multiple others (Dowse 2017).

This theme of composition in others continues in the largest part of the installation located on the 
(a)

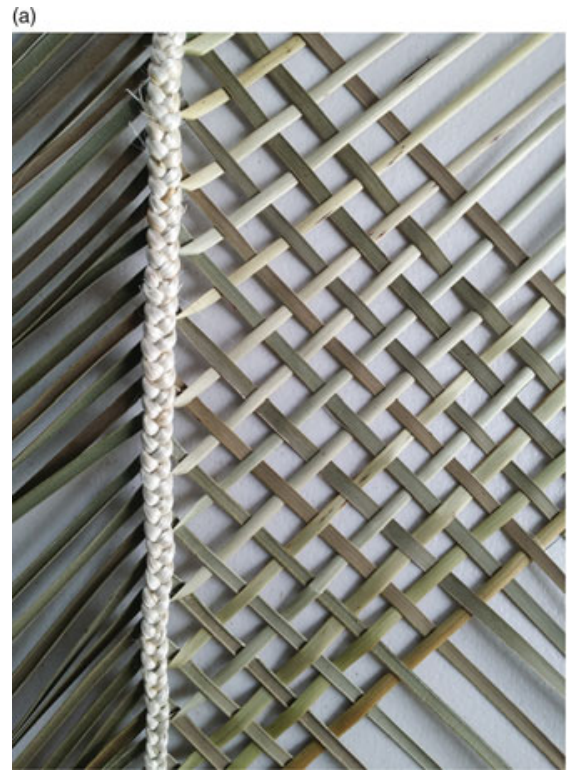

(b)

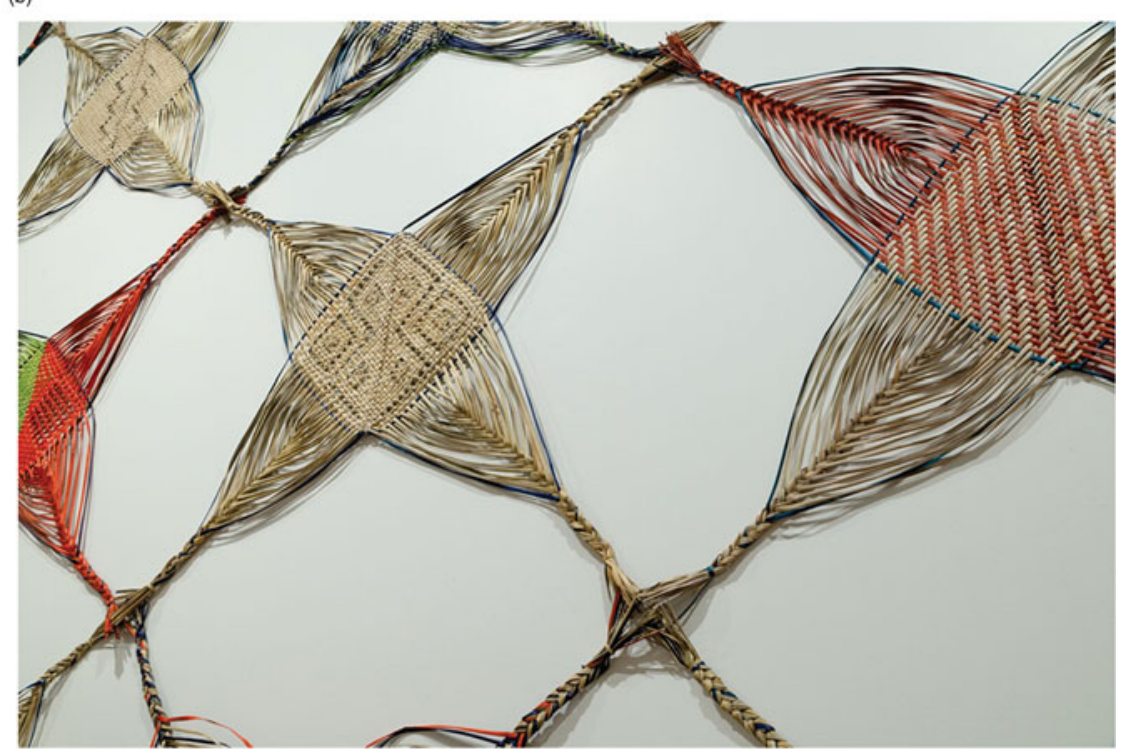

Figure 4. (Left) The foundation braid and initial weaving for a section of Flat-pack Whakapapa. Maureen Lander, Whiri Commencement (Whakapapa) for Flat-Pack Whakapapa (work in progress) 2017. (Photograph: courtesy of the artist.) (Right) Detail of several whakapapa sections of Kit-Set Whanaungatanga. Note how each section is grown from four foundation braids or whiri, which also join each section to its neighbours. (Photograph: Shaun Matthews.)

left wall, Kit-Set Whanaungatanga. It is a collaborative work by Maureen and a group of weavers called her A-team-her awhina team, meaning to help and befriend. Kit-set Whaunangatanga is about family (whanau) and our social networks of kin, friends, colleagues and others. As in Flat-Pack Whakapapa, each person is a kete woven from a single foundation braid (whakapapa) and completed with four finishing braids which reach out and join directly to four more, and on from them to all others (Figs $3 \& 4$ ). All members of the A-team wove several kete, 'each with a predetermined set of criteria that included technique, size, colour and pattern. Even so, as in the narrating of whakapapa, every weaver had some freedom to express their skills, creativity and individuality' (Dowse 2017).

Flat-Pack Whakapapa visually and conceptually sets out the fundamental principles of whakapapa while also asking us to question, challenge and critique claims which potentially erode its open, situated way of knowing-claims which run counter to its ethical and moral foundations. It is these characteristics of whakapapa which make it powerful in Maori lives, and potentially also as academic theory.

\section{Applying whakapapa in New Zealand scholarship}

For many years, Mere Roberts has championed whakapapa as scientific and social theory. It is largely through her work that the application of whakapapa has moved beyond Maori scholarship and practice into scientific research (M. Roberts 2010; 2012; 2013; M. Roberts et al. 2004). Roberts trained as a biologist, initially in zoology, but her work is fundamentally interdisciplinary, cross-cultural and collaborative. She has held academic positions in biology, medicine, environmental science and anthropology, publishing widely across these fields. In its open engagement across the layered worlds of academic disciplinary practices, and across Maori and sciencebased ontologies, her career exemplifies whakapapa in practice.

Roberts' whakapapa of natural and material worlds have been especially influential. Using the whakapapa of kumara or sweet potato, Ipomea batatas, as her starting-point, she draws out how 'Maori knowledge concerning the origin and relationships of material things like the kumara is visualised as a series of co-ordinates arranged upon a collapsed time-space genealogical framework' (M. Roberts 2012, 40). There are fascinating resonances here with the work of geographer Doreen Massey (2005). A key principle is 'ascribing origins and the "coming into being" (or ontology) of each known thing' (M. Roberts 2012, 41), a relational process which may draw in varying combinations of plants and animals, and 'permits the inclusion of nonbiological phenomena' such as celestial bodies, 
while also precluding any possibility of a nature/ culture divide (M. Roberts 2012, 40-41).

Stepping off from Roberts work, whakapapa has been employed to evaluate emerging new biotechnologies such as GMO Generically Modified Organisms (Gillett 2009; Hudson et al. 2012; M. Roberts et al. 2004). The relational character of whakapapa makes it especially well-suited to studies which evaluate combinations of factors, for example the intertwining of genetic and environmental factors which underlie distinctive patterns of disease and ill-health in Maori communities (Hudson et al. 2007). Park et al. (2011) chose a whakapapa approach to examine the spread and impact of tuberculosis in Pacific populations. Tuberculosis is well known to have social as well as biological and environmental risk factors, and in their study Park et al. highlight among other influences the critical impact of immigration policies, calling into question the ethical and moral principles embodied in these policies.

Two features of this emerging body of work stand out. First, it is fundamentally located in debates concerning the moral and ethical contexts of research. Hudson et al. $(2007,45)$ speak in particular of 'dual accountability', the requirement both to be accountable to the interests of Maori kin and community and to enforce rigorous academic research practice. While often uncomfortable, these dual pressures do have the power to enrich and enhance standards of research practice (cf. O'Regan 2010; Rika-Heke 2010). Secondly, the majority of work engaging with whakapapa has been directed towards the development of culturally informed social policies, rather than seeking solutions to scientifically defined research questions. This is in part because reframing the moral and ethical context of research through whakapapa inevitability challenges the appropriateness and applicability of the questions being asked. In other words, it not necessarily the case that Maori theory such whakapapa cannot inform research solutions, but rather that we have been asking scientific questions of little relevance to Maori. A broadening of research objectives might draw in Maori scholars and enrich scholarly debate more generally.

\section{Applying whakapapa in archaeology-an international reach?}

The qualities of whakapapa which I have chosen to highlight are its moral and ethical embeddedness and its insistence on contextually informed, multiple forms of relating. These qualities have strong resonances with other open-ended methodologies and posthumanist theories employed by archaeologists, particularly feminist writers such as Karen Barad, Elizabeth Grosz and Donna Haraway (see Alberti \& Marshall 2009; Marshall 2000; 2008; Marshall \& Alberti 2014). They also resonate closely with Joan Gero's call to value, even highlight, the ambiguities inherent in all archaeological data (Gero 2007; 2015).

In recent work, I have employed whakapapa as archaeological method and theory for the analysis of Maori whalebone pendants-objects which are considered artworks (Lyons \& Marshall 2014; Marshall 2020; Marshall \& Alberti 2014). With the exception of one small fragment, none of these objects have secure archaeological provenance, so although they are exceptional in many ways, they are difficult to interpret and little has been written about them. My purpose was to use a whakapapa approach to open up our thinking about these objects to new possibilities. By drawing on a wider range of data, including the work of contemporary bone carver Brian Flintoff (2011), I sought to develop a broader understanding of their meaning and significance in Maori lives past and present. Whakapapa was a particularly appropriate analytical choice for these objects, because in themselves they embody whakapapa. Their design and narrative materializes both a specific telling of whakapapa and the principles on which whakapapa is founded.

My application of whakapapa stayed close to its Maori and New Zealand origins, and it follows the well-trodden path in archaeology of employing indigenous theory to explore art objects. However, whakapapa has the potential for greater reach, beyond New Zealand and beyond archaeological art objects.

Given the forums in which whakapapa has already entered academic debate in New Zealand, an obvious area of international research where it could make a contribution is the application of genetics in archaeological studies. This new and fast-moving field is symptomatic of two features of contemporary archaeological research: the extraordinarily large bodies of data which can now be produced, sometimes very simply and cheaply, and the extraordinarily rich array of interdisciplinary forms of data potentially available to address any archaeological question. Employing these vast, diverse databases effectively and appropriately presents stiff challenges. An object lesson in just how challenging this might prove is the development of radiocarbon dating. There has been a very long road through initial simplistic assumptions, confusions and 
contradictions, repeated programmes of radiocarbon hygiene, to reach radiocarbon enlightenment and confidence. A similar path is envisaged for the application of contemporary and ancient DNA research in archaeology. Limitations in western evolutionary theories encourage simplistic, reductionist interpretations (see Ingold 2007; 2011; SAA 2019, for critiques). Lessons in building cross-cultural approaches to scientific practice, already being addressed in New Zealand as whakapapa becomes more widely employed, could inspire new modes of analysis and lead to more insightful outcomes.

For example, we might try weaving insights from Mere Roberts' whakapapa of kumara, sweet potato, with analysis of the genetics of modern Pacific sweet potato varieties and ancient DNA analyses of the small selection of archaeological specimens recovered in the Pacific. The aim would be a uniquely interdisciplinary, cross-cultural whakapapa of Pacific sweet potatoes. The foundation braid for such an analysis might focus on the homeland of sweet potato, South America. On the other hand, given the diversity of conventional and novel data available, a new form of foundation and weaving technique might be needed. When Toi Te Rito Maihi began weaving kete from seaweed in 1992, she quickly learnt that, due to the brittle nature of the drying seaweed, a conventional foundation braid and weaving technique could not work. A specific weaving technique tailored to each type of seaweed or kelp was in fact required (Maihi \& Lander 2008, 72-4). To employ whakapapa as scientific and social theory will similarly require improvization and innovation.

A case in point is how to interpret the past of Pacific people. Conventional archaeological accounts of Pacific prehistory have generally sought to distil out master narratives from multiple strands of evidence. For example, Kirch and Green (2001) employed a process they described as triangulation. Evidence from three disciplines, linguistics, ethnology and archaeology, was triangulated to identify points of convergence and produce a distilled essence for interpretation of past events. Many more forms of evidence have since become available. Especially prolific are data arising from genetic analyses of people, plants and animals. Fortunately, however, whakapapa works in the opposite way to triangulation. Rather than distilling down, whakapapa opens up the evidence base, drawing in and weaving together multiple strands of diverse data, while also seeking to maintain the disciplinary integrity of each strand. It is an approach well suited to our surprising new condition of overwhelming riches of data.

\section{Conclusion}

Whakapapa is well-established in New Zealand as both theory and practice. It is fundamental to Maori society, past and present, and it has emerged as a powerful forum for the development of social policy in a range of contexts. It is also increasingly employed to inform academic research across a variety of disciplines. My primary purpose in this paper has been to bring this work on whakapapa to the attention of an international audience. With this in mind, I have highlighted those features of whakapapa which have already demonstrated power to inform interdisciplinary and cross-cultural research, and to challenge our research cultures. Above all, whakapapa is purposeful, engaged research. It demands work where something is actually at stake for all participants and subjects. Such work produces both novel insights and morally and ethically enriching outcomes.

\section{Acknowledgements}

This paper would never have been written without the encouragement and advice of Maureen Lander, Toi Re Rito Maihi and Julie Park. Many thanks to Maureen Lander, and to The Dowse Art Museum for permission to use images from Flat-Pack Whakapapa. Thank you to Penny Copeland for her beautiful figure drawings.

Yvonne Marshall
Archaeology
University of Southampton
University Road
Southampton SO17 1BJ
UK
Email: ymm@soton.ac.uk

\section{References}

Alberti, B., S. Fowles, M. Holbraad, Y. Marshall \& C.L. Witmore, 2011. 'Worlds otherwise': archaeology, anthropology and ontological difference. Current Anthropology 52(6), 896-912.

Alberti, B. \& Y. Marshall, 2009. Animating archaeology: local theories and conceptually open-ended methodologies. Cambridge Archaeological Journal 19(3), 344-56.

Deloria, V., Jr, 2003. God is Red: A native view of religion. (30th anniversary edn.) Golden (CO): Fulcrum Publishing.

Dowse, 2017. Maureen Lander: Flat-Pack Whakapapa. Four Installations. Lower Hutt: Dowse Art Museum.

Dowson, T.A., 1998. Like people in prehistory. World Archaeology 29(3), 333-43. 
Flintoff, B., 2011. Kura Koiwi: Bone treasures. Nelson, NZ: Craig Potton Publishing.

Gero, J.M., 2007. Honouring ambiguity; problematizing certitude. Journal of Archaeological Method and Theory 14(3), 311-27.

Gero, J.M., 2015. Yutopian: Archaeology, ambiguity and the production of knowledge in northwest Argentina. Austin (TX): University of Texas Press.

Gillett, G., 2009. Indigenous knowledges: circumspection, metaphysics, and scientific ontologies. Sites 6(1), 1-19.

Haraway, D.J., 1991. Simians, Cyborgs and Women: The reinvention of nature. New York (NY): Routledge.

Henare, A., 2007. Toanga Maori: encompassing rights and property in New Zealand, in Thinking Through Things: Theorising artefacts ethnographically, eds A. Henare, M. Holbraad \& S. Wastell. London: Routledge, 47-67.

Hountondji, P.J., 2002. Knowledge appropriation in a postcolonial context, in Indigenous Knowledge and the Integration of Knowledge Systems: Towards a philosophy of articulation, ed. C.A.O. Hoppers. Claremont: New Africa Books, 23-38.

Hudson, M.L., A.L.M. Ahuriri-Driscoll, M.G. Lea \& R. A. Lea, 2007. Whakapapa - a foundation for genetic research? Bioethical Enquiry 4, 43-9.

Hudson, M., M. Roberts, L. Smith, S. Tiakiwai \& M. Hemi, 2012. The art of dialogue with indigenous communities in the new biotechnology world. Genetics and Society 31(1), 11-24.

Ingold, T., 2007. Lines: A brief history. London: Routledge.

Ingold, T., 2011. Being Alive: Essays on movement, knowledge and description. London: Routledge.

Kirch, P.V. \& R. Green, 2001. Hawaiki, Ancestral Polynesia. Cambridge: Cambridge University Press.

Lander, M., 2017. Maureen Lander: Flat-Pack Whakapapa. Four Installations. The Dowse Art Museum, Lower Hutt. https://govettbrewster.com/exhibitions/maureenlander-flat-pack-whakapapa

Lyons, N. \& Y. Marshall, 2014. Memory, practice, telling community. Canadian Journal of Archaeology 38, 496-518.

Lythberg, B. \& C. McCarthy (eds), 2019. 'Te Ao Hou: Whakapapa as practical ontology'. Special issue, Journal of the Polynesian Society 128(1).

Mahuika, N., 2019. A brief history of whakapapa: Māori approaches to genealogy. Genealogy 3(32), 1-13.

Maihi, Toi Te Rito \& M. Lander, 2008. He Kete He Kōrero: Every kete has a story. Auckland: Penguin.

Marshall, Y., 2000. Reading images stone B.C. World Archaeology 32(2), 222-35.

Marshall, Y., 2008. Archaeological possibilities for feminist theories of transition and transformation. Feminist Theory 9(1), 25-45.

Marshall, Y., 2020. Taking Indigenous theory seriously: whakapapa and chevron amulets, in Theory from the Pacific, the Pacific in Theory: Archaeological perspectives, ed. T. Thomas. London: Routledge. 299-328.
Marshall, Y. \& B. Alberti, 2014. A matter of difference: Karen Barad, ontology and archaeological bodies. Cambridge Archaeological Journal 24(1), 19-36.

Massey, D., 2005. For Space. London: Sage.

Mata Aho Collective 2017. An art matriarch: why Maureen Lander is a boss. The Pantograph Punch. https://www. pantograph-punch.com/post/ode-to-maureen-lander (accessed 23 July 2019).

McCarthy, C. \& P. Tapsell, 2019. Te Poari Whakapapa: the origins, operation and tribal networks of the Board of Maori Ethnological Research 1923-1935. Journal of the Polynesian Society 128(1), 87-106.

Neich, R., 1993. Painted Histories: Early Maori figurative painting. Auckand: Auckland University Press.

Neich, R., 2001. Carved Histories: Rotorua Ngati Tarawhai wood carving. Auckand: Auckland University Press.

Ngata Apirana, 2019. The terminology of whakapapa. Journal of the Polynesian Society 128(1), 19-41.

Nicholas, G. (ed.), 2010. Being and Becoming Indigenous Archaeologists. Walnut Creek (CA): Left Coast Press.

O'Regan, G., 2010. Working for my own, in Being and Becoming Indigenous Archaeologists, ed. G. Nicholas. Walnut Creek (CA): Left Coast Press, 235-45.

Paama-Pengelly, J., 2010. Maori Art and Design: Weaving, painting, carving and architecture. Auckland: New Holland Publishers.

Park, J., J. Littleton, A. Chambers \& K. Chambers, 2011. Whakapapa in anthropological research on tuberculosis in the Pacific. Sites 8(2), 6-31.

Rika-Heke, M., 2010. Haere Tika Tona Atu - keep going forward, in Being and Becoming Indigenous Archaeologists, ed. N. George. Walnut Creek (CA): Left Coast Press, 267-76.

Roberts, J., 2006. Layer upon Layer, Whakapapa. Cambridge, NZ: Wotz Wot.

Roberts, M., 2010. Mind maps of the Maori. GeoJournal 77 (6), 1-11.

Roberts, M., 2012. Revisiting 'The Natural World of the Maori', in Huia Histories of Māori: Ngā tāhuhu kōrero, ed. D. Keenan. Wellington: Huia, 33-56.

Roberts, M., 2013. Ways of seeing: Whakapapa. Sites 10(1), 93-120.

Roberts, M., B. Haami, R. Benton, T. Scatterfield, M. L. Finucane, M. Henare \& M. Henare, 2004. Whakapapa as a Maori mental construct: some implications for the debate over genetic modification of organisms. Contemporary Pacific 16(1), 1-28.

SAA 2019. 'Bones and Chromosomes: the ancient DNA revolution in archaeology (Part 1)'. Special Section, The SAA Archaeological Record 19(1), 15-42.

Salmond, A.J.M., 2019. Comparing relations: whakapapa and genealogical method. Journal of the Polynesian Society 128(1), 107-29.

Salmond, A. \& B. Lythberg, 2019. Spiralling histories: reflections on the 1923 Dominion Museum East Coast Ethnological Expedition and other multimedia experiments. Journal of the Polynesian Society 128(1), 43-63. 
Starzecka, D.C., R. Neich \& M. Pendergrast, 2010. The Maori Collections of the British Museum. London: British Museum Press.

Tomášková, S., 2013. Wayward Shamans: The prehistory of an idea. Berkeley (CA): University of California Press.

Viveiros de Castro, E., 1998. Cosmological deixis and Amerindian perspectivism. Journal of the Royal Anthropological Institute 4(3), 469-88.

Viveiros de Castro, E., 2004. Exchanging perspectives: the transformation of objects into subjects in Amerindian ontologies. Common Knowledge 10(3), 463-84.
Willerslev R., 2007. Soul Hunters: Hunting, animism, and personhood among the Siberian Yukaghirs. Berkeley (CA): University of California Press.

\section{Author biography}

Yvonne Marshall is an Associate Professor of Archaeology at the University of Southampton. She has worked in many parts of the Pacific, including New Zealand, Fiji, Taiwan and British Columbia. She is currently focusing on the application within archaeology of relational theories which emerge from feminist thinking. 